\title{
Agroforestry mapping and characterization in four districts of Garhwal Himalaya
}

\author{
Subhasis Mahato $^{1} \cdot$ Sabyasachi Dasgupta $^{1} \cdot$ N. P. Todaria ${ }^{1}$ V. P. Singh $^{2}$ \\ ${ }^{1}$ Department of Forestry and NR, H.N.B. Garhwal University, Srinagar (Garhwal), Garhwal, Uttarakhand 246174, India \\ ${ }^{2}$ ICRAF- Regional Office for South Asia, ICRAF, 1st Floor National Agricultural Science Complex (NASC), Dev Prakash Shastri Marg, Pusa, \\ New Delhi, Delhi 110012, India
}

Received: 31 August 2015/Revised: 7 January 2016/Accepted: 15 March 2016/Published online: 31 March 2016

(C) Joint Center on Global Change and Earth System Science of the University of Maryland and Beijing Normal University and Springer-Verlag Berlin Heidelberg 2016

\begin{abstract}
Farmers in the Indian Himalayan region have been practicing agroforestry since time immoral. Agroforestry practice complements hill farming and forms the backbone of subsistence agriculture. The present study was carried out in four districts of Garhwal Himalaya. Agroforestry area was demarcated using Remote Sensing and Geographic Information System techniques. The information regarding agriculture and tree crop pattern was collected through questionnaire survey and direct observations. The agri-horti-silviculture is very common practice of this region. As compared to geographical area the net sown area is very low with wide variations within study area. A small portion of the net sown area has been utilized for the agroforestry purpose. Topographical factors play a crucial role in utilization of the land for agroforestry purpose. Highest agroforestry area, as well the highest agroforestry land as percentage of total geographical area, was estimated as $2.13 \%$ in one of the district of study area. Within 300-7100 m a.s.l. of study area, maximum agroforestry was found in 1201-1600 m a.s.l. altitudinal zone and in $21^{\circ}-30^{\circ}$ slope. Cropping pattern is dominated by the traditional and low productivity crops, providing basic livelihood for a vast majority of the population. Many farmers in the Garhwal Himalayan areas are struggling to
\end{abstract}

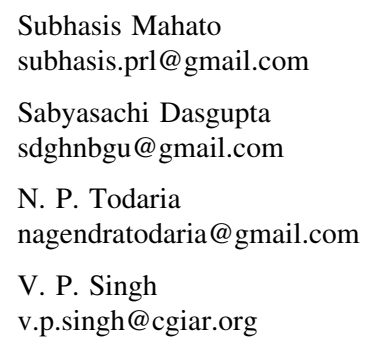

make a livelihood due to lack of other avenues of employment and small land holdings, leading to migration of mountain people toward plains. It is presumed that the rate of migration can be reduced once the agroforestry potential of this area is harnessed at an optimum level.

Keywords Agroforestry · Altitude · Slope · GIS · Garhwal Himalaya

\section{Introduction}

In India agroforestry meets almost half of the demand of fuel wood, two-thirds of the small timber, 70-80 \% wood for plywood, $60 \%$ of raw material for paper pulp, and $9-11 \%$ of the green fodder requirement of livestock, besides meeting the subsistence needs of households for food, fruit, fiber, medicine, etc. (NRCAF, Vision 2050). The farmers of this region started diversifying the cropping system, and in order to reduce the degree of risk and vagaries of climate, many crop species were sown together. This practice was traditionally called as 'Baranaja' cropping system, which led to a symbiosis relationship between different plants and contributed to increased productivity of crops (Kothari 1994; Shiva 1996). This indigenously evolved cropping system of Baranaja, later transformed into agroforestry system to cope with the monsoon failure and change in climate. Local people designed the indigenous agroforestry system in such a way so that the livelihood requirement may be maintained even in the lean periods. Nonetheless, in extreme situations, people started migrating from one place to other for sustaining the burden of survival. Traditionally, hill farmers have maintained 
close linkages and balances between agriculture, forestry, and animal husbandry, and based on these linkages, the land use patterns are determined in the hills (Maikhuri et al. 2009).

Agroforestry is key path to prosperity for millions of farm families leading to extra income, employment generation, greater food and nutrient security, and meeting other basic human needs in a sustainable manner (Dhyani et al. 2009).

The agri-horti-silviculture is very common practice of Garhwal Himalayan region, which includes the cultivation of agricultural crops in association with forest and horticultural trees. The arrangement of agri-horti-silviculture system on the same piece of land provides the stable and better output to the farmers. It is important to mention that in hilly regions the existence without agroforestry is difficult because trees not only supplement the fodder, fuel, fiber, fruits etc., but also reduce the pace of land sliding, protect crops against adverse wind and climatic condition, conserve the moisture, and improve the soil quality through organic matter in terms of leaf fall. Majority of indigenous hill agricultural systems in the Garhwal Himalayan region of India are operated in the rain-fed areas, and therefore, the onset of monsoon is the crucial determinant for the hill farmers. Historically, the abundant rains during summer and rainy seasons helped farmers to expand their agricultural practices and grow a variety of cereals and pulses (Shiva and Vanaja 1993; Singh and Jardhari 2001).

Though a number of studies on Himalayan agroforestry systems are available (Toky et al. 1989; Gilmour and Nurse 1991; Ralhan et al. 1991; Sundriyal et al. 1994; Thapa et al. 1995; Sharma et al. 1995; Semwal and Maikhuri 1996; Singh et al., 1997; Dhyani and Sharda 2005; Dhyani et al. 2009), there is scanty or no reliable data available to show area under agroforestry in the region.

Therefore, a study was undertaken to estimate the area under agroforestry using Remote Sensing (RS) and Geographic Information System (GIS) techniques.

\section{Materials and methods}

\subsection{Study area}

The state of Uttarakhand lies between latitudes $28^{\circ} 43^{\prime} \mathrm{N}$ to $3127 \mathrm{~N}$ and longitudes $77^{\circ} 34^{\prime} \mathrm{E}$ to $81^{\circ} 02^{\prime} \mathrm{E}$, with a total geographical area of $53,484 \mathrm{~km}^{2}$ (1.6\% of total area of the country). It has forest area of $34,651 \mathrm{~km}^{2}$ and area under agriculture is $13,370 \mathrm{~km}^{2}$ (Kumar 2010). The state is administratively divided into two divisions Kumaon and Garhwal, and has 13 districts. In present study four districts of the Garhwal region (Chamoli, Pauri, Rudraprayag, and Tehri) were selected (Fig. 1). All four districts fall in
Alaknanda-Bhagirathi basin. The region has subtropical to temperate climate governed by altitude which remains pleasant throughout the year on an average except high altitudes.

\section{Methodology}

Google Earth pro data of 2011 were used for demarcation of agroforestry area. Demarcated area was further corrected through ground truth. Delineation of slope and elevation was based on Advanced Spaceborne Thermal Emission and Reflection Radiometer (ASTER) Global Digital Elevation Model (GDEM) data of 2011. The relevant Survey of India (SOI) topographic maps were geometrically rectified in 1:50,000 scale using geographic projection system UTM (Universal Transverse Mercator); speroid and used datum were WGS 84 (World Geodetic System 1984) with UTM zone 44. The GIS and image processing software used were ArcGIS 9.1 and ERDAS Imagine 9.3. The paradigm for the study is described in Fig. 2. Small-size patches of agroforestry of less than one hectare were not isolated due to less precise data from images. Field verification was carried out during August 2012. Thirty households located at different altitudes in different districts were surveyed to collect information on type of tree species planted in the agriculture fields, types of services provided by these trees, and seasonal pattern of harvest. Information on agriculture crop grown in different seasons was also obtained during the survey.

\section{Results}

In Uttarakhand, people practice integrated system of farming including agriculture, forestry, horticulture, and livestock rearing. In the study area, Chamoli district has the highest geographical area followed by Pauri, Tehri, and Rudraprayag. There are wide variations among districts in terms of percent net sown area under agriculture and agroforestry system. The highest net sown area has been found in Pauri district $(18.88 \%)$ followed by Tehri (14.81\%), Rudraprayag (7.59\%) and Chamoli (4.38\%; Table 1). It is because of the fact that tarai bhabar (plain) is located in Pauri district, while Chamoli is located in high hills. It is worth to mention that remunerative agriculture is possible only in valleys. Highest agroforestry land has been found in Tehri $(2.13 \%)$, followed by Pauri $(1.05 \%)$, Chamoli (0.75\%), and Rudraprayag (0.62\%).

Rudraprayag district have highest forest area, as a result fuel, fodder, and small timber collections are within easy reach of people. This could be one of the reasons behind low agroforestry area, but same is not true for Chamoli as 


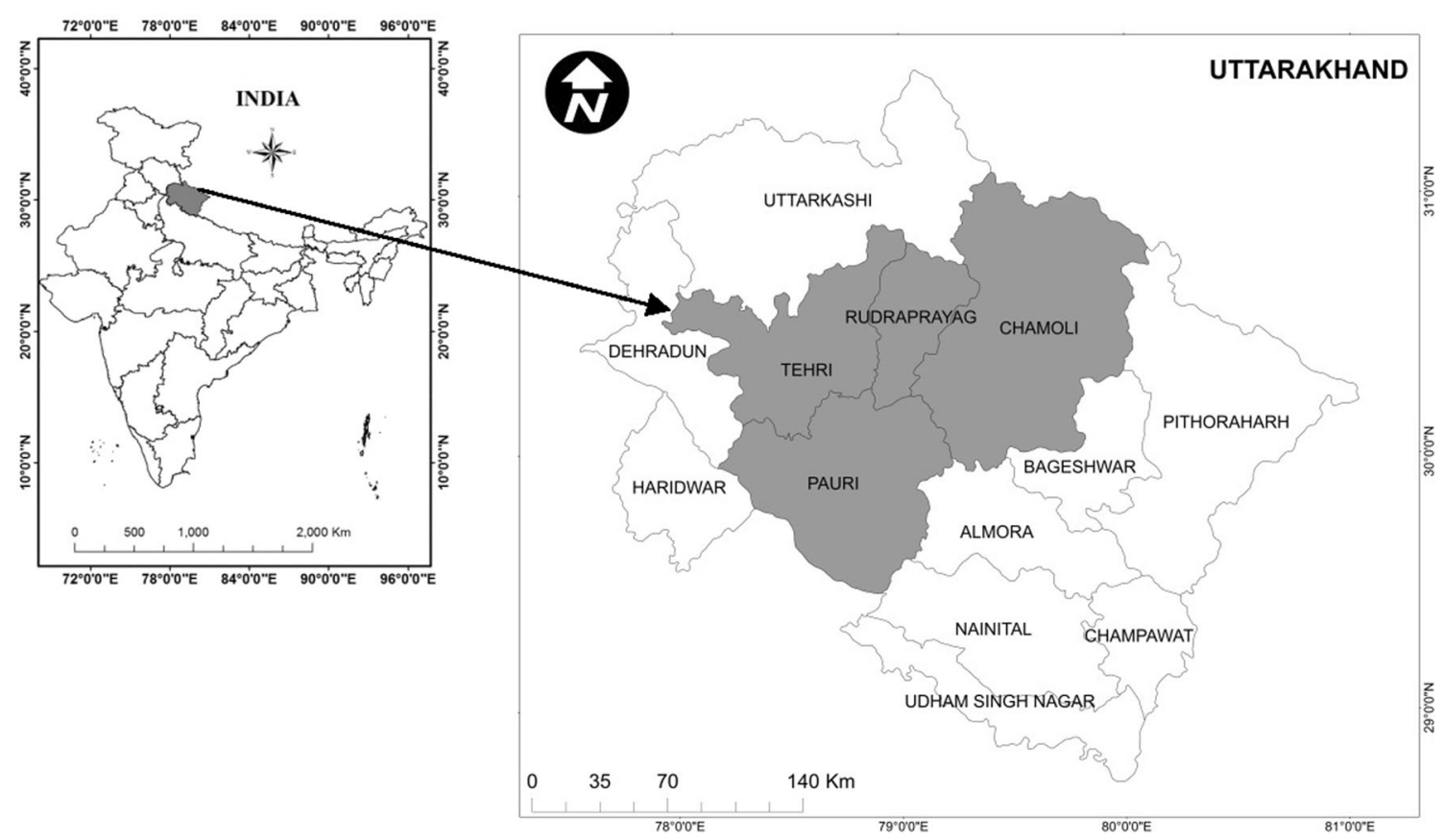

Fig. 1 Study area map

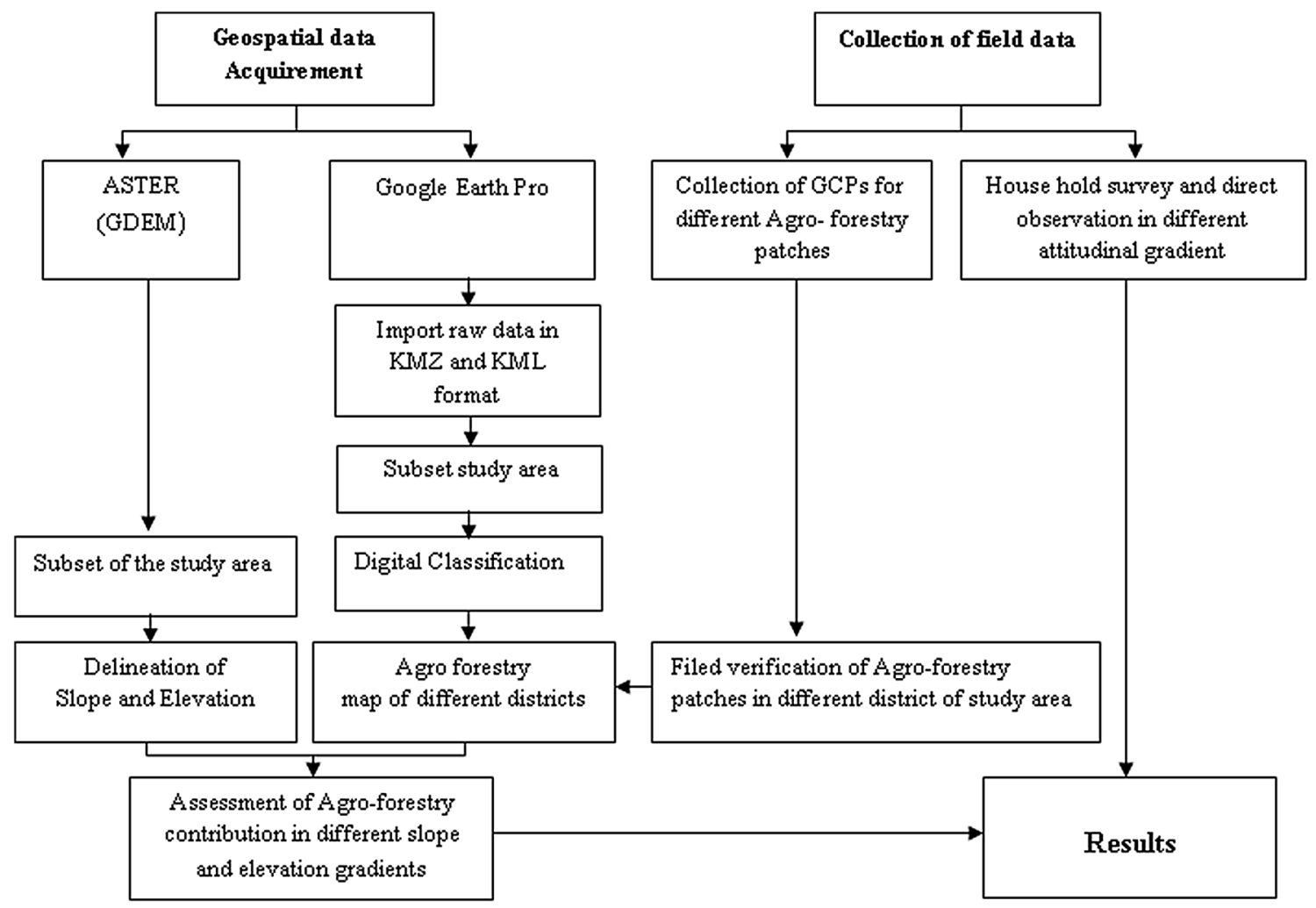

Fig. 2 Paradigm for assessing the agro-forestry in relation to slope and elevation

in spite of having lowest forest cover, it did not contain higher area under agroforestry. Here the reason could be the inaccessibility and difficult terrain condition.
Study area ranged from 300 to $7100 \mathrm{~m}$ a.s.l. To understand the altitudinal effect on practice of agroforestry in these hills, the study region was divided into various 
altitudinal zones. In this altitudinal gradient the climatic conditions vary from subtropical to alpine. Agroforestry in these hilly areas is practiced on terraces carved out of steep slopes between 800 and $2800 \mathrm{~m}$ a.s.l. only. In district Chamoli the highest geographical area has been found in altitudinal zone of 4000-7100 m a.s.l. (44.73\% consisting of high mountains and snow clad peaks). On the contrary, the highest agroforestry area has been found in altitudinal zone of $1201-1600 \mathrm{~m}$ a.s.l. (50.61\%), followed by 1601-2000 (22.51\%) and 801-1200 m a.s.l. (18.69\%). In district Pauri highest geographical area has been found in altitudinal zone of $>800 \mathrm{~m}$ a.s.l. (33.5\%), followed by 801-1200 (23.15\%) and 1201-1600 m a.s.l. (23.03\%), whereas the highest agroforestry area has been found in altitudinal zone of 1201-1600 m a.s.l. (44.84 \%), followed by $801-1200 \mathrm{~m}$ a.s.1. (44.24 \%; Fig. 3).

In case of Rudraprayag district, the highest geographical area has been found in altitudinal zone of $3601-4000 \mathrm{~m}$ a.s.l. (43.69\% again consisting of high hills and snow covered mountains), followed by $3201-3600 \mathrm{~m}$ a.s.l. (15.98\%) and 1201-1600 (Fig. 3). On the contrary, the highest agroforestry area has been found in altitudinal zone of $801-1200 \mathrm{~m}$ a.s.l. (48.68 \%), followed by $1201-1600$ (36.62 \%) and 1601-2000 (13.65 \%). Similar to Chamoli, Rudraprayag district has nearly half of the geographical area in the higher alpine zone but the highest area of agroforestry has been found in the subtropical zone. The density of human population in higher mountains is thin,

Table 1 Data on geographical, net sown and agroforestry area in different districts

\begin{tabular}{lllll}
\hline District & $\begin{array}{l}\text { Total geographical } \\
\text { area }\left(\mathrm{GA}, \mathrm{km}^{2}\right)^{\mathrm{a}}\end{array}$ & $\begin{array}{l}\text { Net sown area (NSA) } \\
\text { out of GA }(\%)\end{array}$ & $\begin{array}{l}\text { Agroforestry area } \\
\text { out of GA }(\%)\end{array}$ & $\begin{array}{l}\text { Total forest area } \\
(\%) \text { of GA }\end{array}$ \\
\hline Chamoli & 8030 & 4.38 & 0.75 & 63.03 \\
Pauri & 5329 & 18.88 & 1.05 & 72.26 \\
Rudraprayag & 1984 & 7.59 & 0.62 & 90.91 \\
Tehri & 3642 & 14.81 & 2.13 & 88.29 \\
\hline
\end{tabular}

${ }^{\mathrm{a}}$ Uttarakhand Forest Statistics-2011-2012

Fig. 3 Altitudinal-wise geographical and agroforestry area of study area
Altitude wise Geographical Area

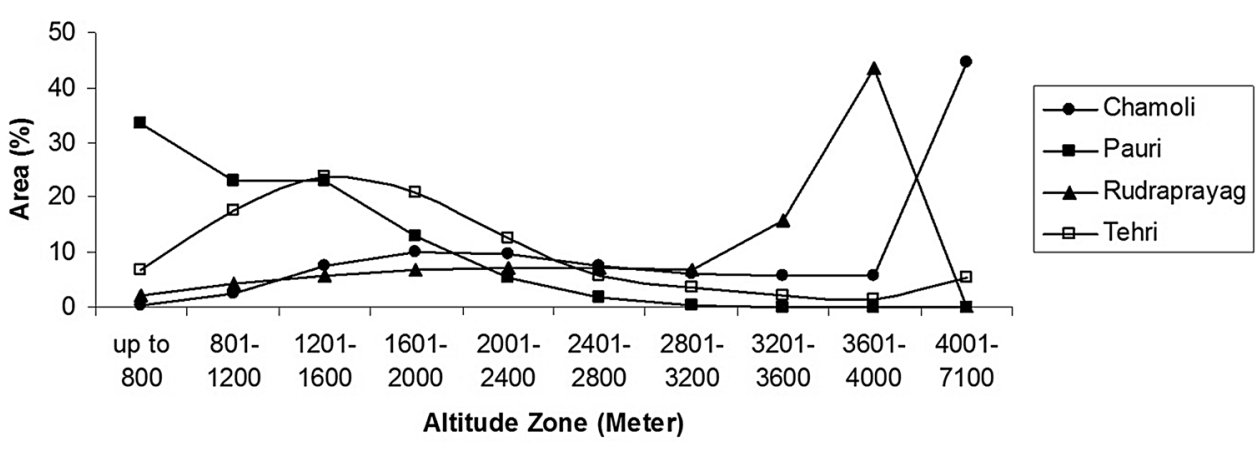

Altitude wise Agroforestry area

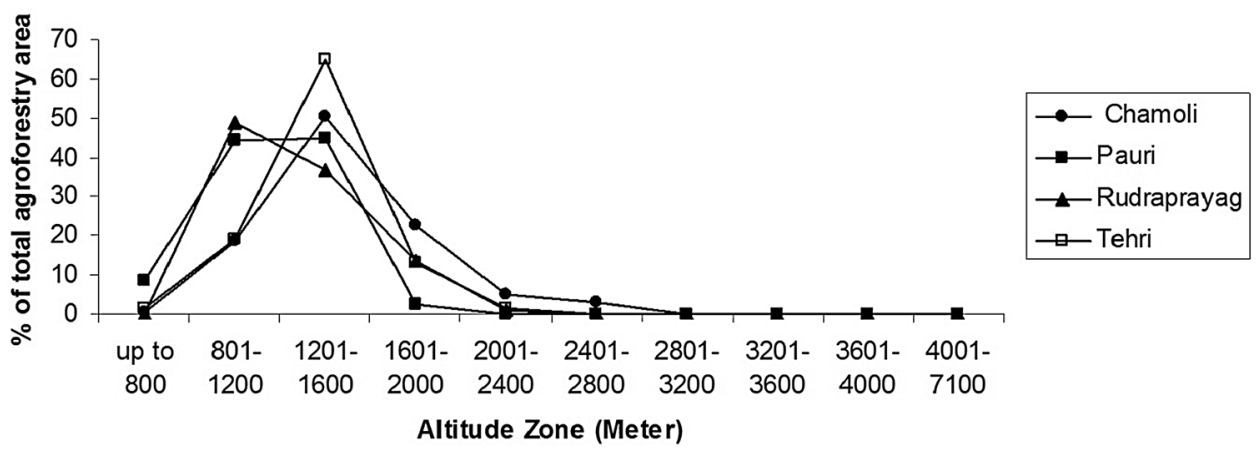


and climatic conditions of alpine and temperate region are not found favorable for agroforestry practice due to the presence of natural forests and this may be the reason that total agroforestry area in these two districts was found less than other two districts. Moreover, sufficient fuel fodder is within carry reach of human populations in temperate zone. In district Tehri the highest geographical area has been found in altitudinal zone of 1201-1600 m a.s.1. (23.75\%), followed by 1601-2000 (20.87\%), 801-1200 (17.65\%) and 2001-2400 $\mathrm{m}$ a.s.1. (12.67\%), whereas the highest agroforestry area has been found in altitudinal zone of 1201-1600 $\mathrm{m}$ a.s.1. (64.73\%), followed by 801-1200 (19\%) and 1601-2000 $\mathrm{m}$ a.s.l. (13.32\%). In all the four districts, nearly half of the agroforestry area has been found in the altitudinal range of 1201-1600 $\mathrm{m}$ a.s.l. followed by 801-1200 and 1601-2000 $\mathrm{m}$ a.s.l. (Fig. 3).

Slope of land is one of the important physiographic aspects influencing the agroforestry land use of Himalayas. Population increase coupled with infrastructure development in the Himalayas has led to extension of cultivation onto steep slopes and other vulnerable lands. Slope of the study area has been classified in five zones, i.e., $\leq 10^{\circ}$ (gentle), $11^{\circ}-20^{\circ}$ (moderate), $21^{\circ}-30^{\circ}$ (high), $31^{\circ}-40^{\circ}$ (steep), and $>41^{\circ}$ (very steep). Slope varied from place to place in all studied districts and ranged up to $>41$. In district Chamoli, the maximum geographical area has been found in slope $11^{\circ}-20^{\circ}(42.35 \%)$ followed by $21^{\circ}-30^{\circ}$ $(31.89 \%)$, and the maximum agroforestry is being practiced in the slope of $21^{\circ}-30^{\circ}(42.5 \%)$ followed by $11^{\circ}-20^{\circ}$ $(27.2 \%)$ and $31^{\circ}-40^{\circ}(23.2 \%)$. In district Pauri, the maximum geographical area has been found in slope $\leq 10^{\circ}$ $(49.78 \%)$ followed by $11^{\circ}-20^{\circ}(25.15 \%)$ and $21^{\circ}-^{\circ} 30^{\circ}$ $(25.02 \%)$ and the maximum agroforestry area was found in slope of $21^{\circ}-30^{\circ}(41.5 \%)$ followed by $11^{\circ}-20^{\circ}$ $(28.5 \%)$ and $31^{\circ}-40^{\circ}$ (16.8\%; Fig. 4). In district Rudraprayag, the maximum geographical area has been found in slope $21^{\circ}-30^{\circ}(37.16 \%)$ followed by $11^{\circ}-20^{\circ}(34.13 \%)$ and $31^{\circ}-40^{\circ}(16.56 \%)$. But the maximum agroforestry area falls in the slope of $21^{\circ}-30^{\circ}(42.7 \%)$ followed by $11^{\circ}-20^{\circ}(28.8 \%)$ and $31^{\circ}-40^{\circ}(19.7 \%)$. In district Tehri, the maximum geographical area has been found in slope $11^{\circ}-20^{\circ}(53.88 \%)$ followed by $21^{\circ}-30^{\circ}(24.52 \%)$ and $\leq 10^{\circ}(19.91 \%)$. However, the maximum agroforestry area falls in the slope of $21^{\circ}-30^{\circ}(43.6 \%)$ followed by $31^{\circ}-40^{\circ}$ $(27.2 \%)$ and $11^{\circ}-20^{\circ}(21.6 \%)$. In all the four districts the maximum agroforestry area has been found in the slope range of $21^{\circ}-30^{\circ}(42.6 \%)$ followed by $11^{\circ}-20^{\circ}(26.5 \%)$ and $31^{\circ}-40^{\circ}(21.7 \%)$. The minimum agroforestry area has been found in the slope $>41(3.2 \%)$ followed by $\leq 10^{\circ}$ (6.0\%; Figs. 4, 5).

After overlaying of elevation and slope through GIS software, maximum agroforestry area $(\%)$ falls in the slope of $21^{\circ}-30^{\circ}$ and $1201-1600 \mathrm{~m}$ a.s.l. elevation followed by slope of $21^{\circ}-30^{\circ}$ and $800-1200 \mathrm{~m}$ a.s.l. elevation (Table 2).

\subsection{Agroforestry and Himalayan land use system}

The land use pattern at lower altitudes of Garhwal area comprises of settlements and irrigated agricultural lands on terraces. Agriculture is the main occupation of most of people in the study area. The trend is similar throughout the Western Himalaya. A number of multipurpose tree species (mainly fodder and fuel wood) are widely cultivated in agroforestry (Bagwari and Todaria 2011). Thirty-two plant species belonging to 17 families (Table 3) were present in different agroforestry systems. Among cereal crops, wheat, barley, gram, lentil, and mustard are grown during the rabi season (October/November to March/April), and rice and maize are grown during kharif season (April/May to September/October). Similarly under cash crops, lemon, elephant citrus, ginger, garlic, and green leaves are grown during rabi season and onion, tomato, cucumber, pumpkin, beans, and green vegetables are grown during kharif season. Crops diversity under cash crops is higher than the cereals.
Fig. 4 Slope-wise agroforestry area $(\%)$ in different districts
Slope wise Agroforestry Area

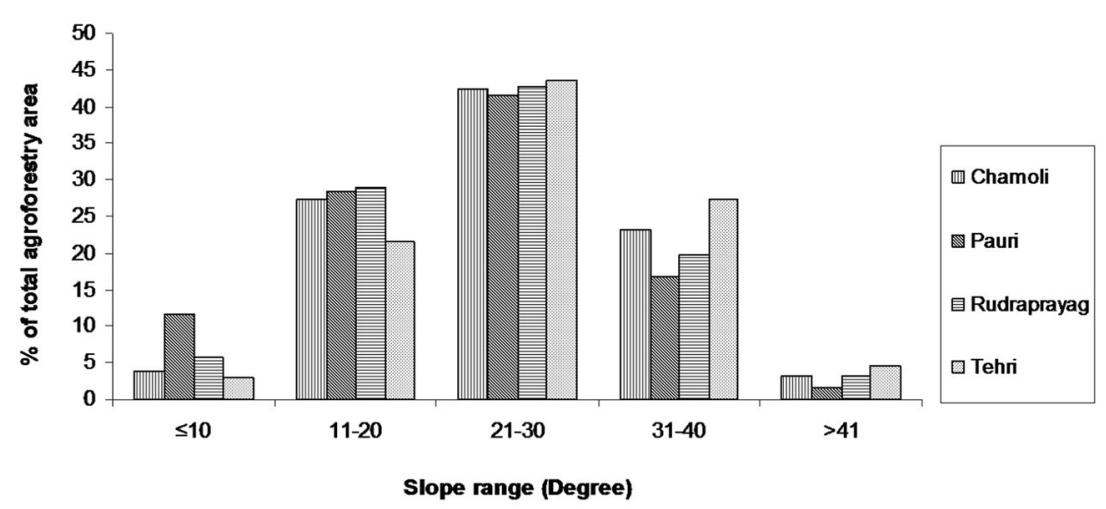



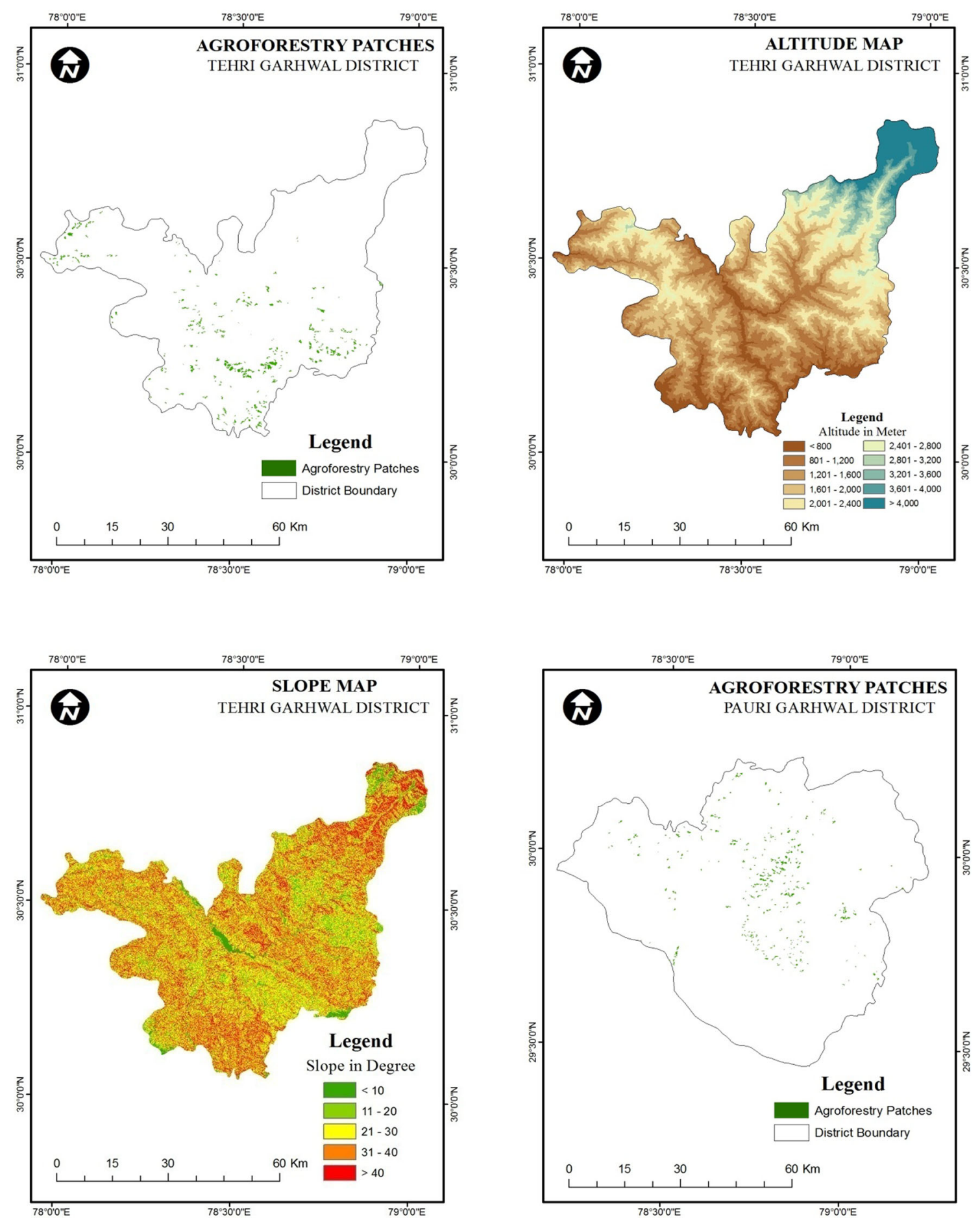

Fig. 5 Agroforestry patches, elevation, and slope map of study area

In the mid-altitude areas of Garhwal region wheat, barley, gram, lentil, and mustard crops are grown under the rabi season, while rice, finger millets, common barnyard grass, horse gram, black gram, soybean, pigeon-pea, rice bean, red kidney beans, and chickpeas are grown during the kharif season. Under cash crops, lemon, elephant citrus, mandarin, orange, ginger, garlic, and green vegetables are grown during the rabi season. During the kharif season, potato, cucumber, pumpkin, beans, pears, peach, nut fruits, and green vegetables are grown. The diversity in cropscereals and cash crops is tremendously high at these altitudes. Sowing and harvesting periods for rabi and kharif 

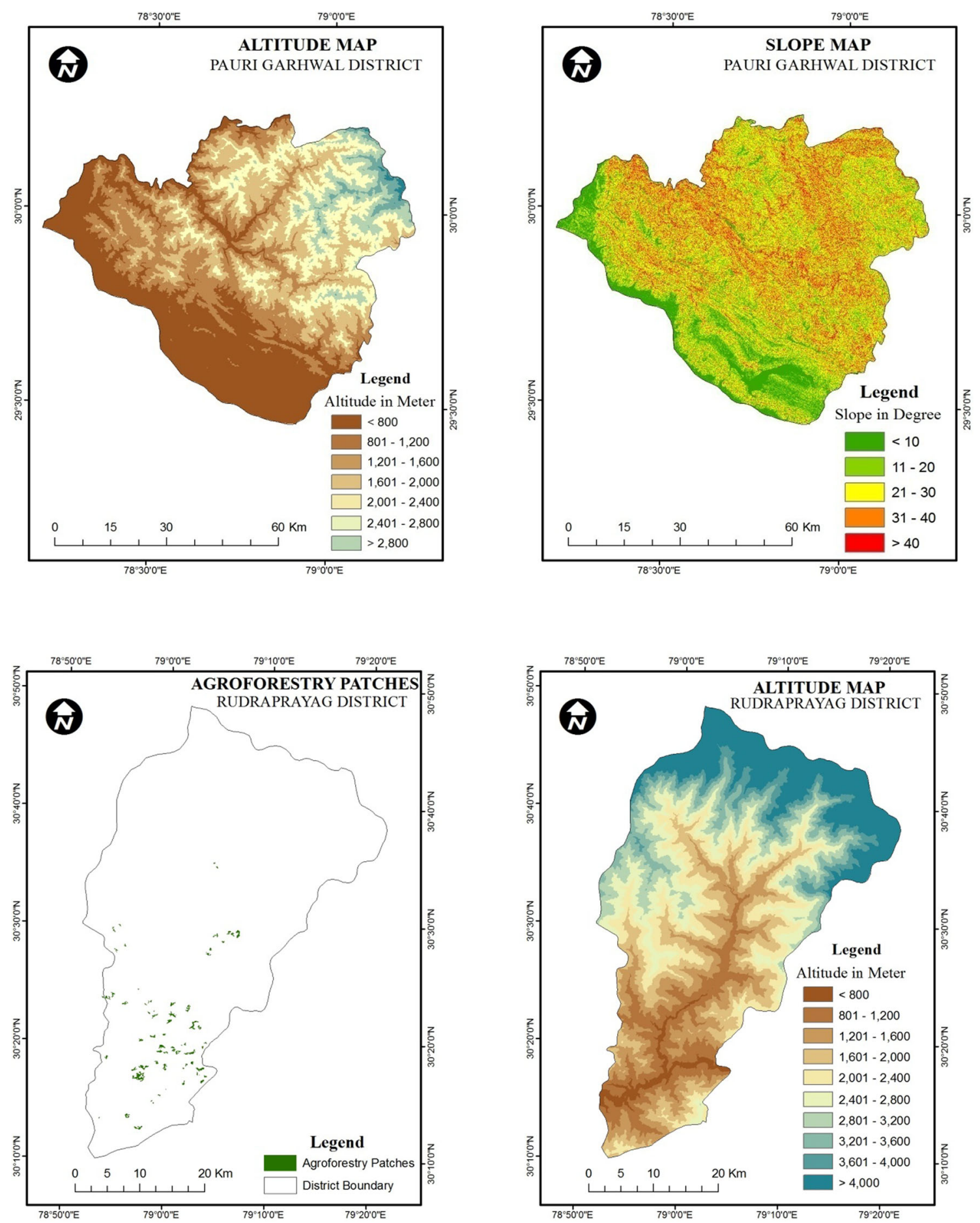

Fig. 5 continued

crops in the highlands slightly go 1 month late than the valley region. Under rabi crops, there are 14 crops grown, out of them five are cereals. Under kharif season, the total number of crops is 25 , and out of them cereals are 13. Agriculture is rain-fed and during the monsoon, enough rainwater is available in this region, and thus maximum crops are grown during monsoon period (Tables 3, 4). 

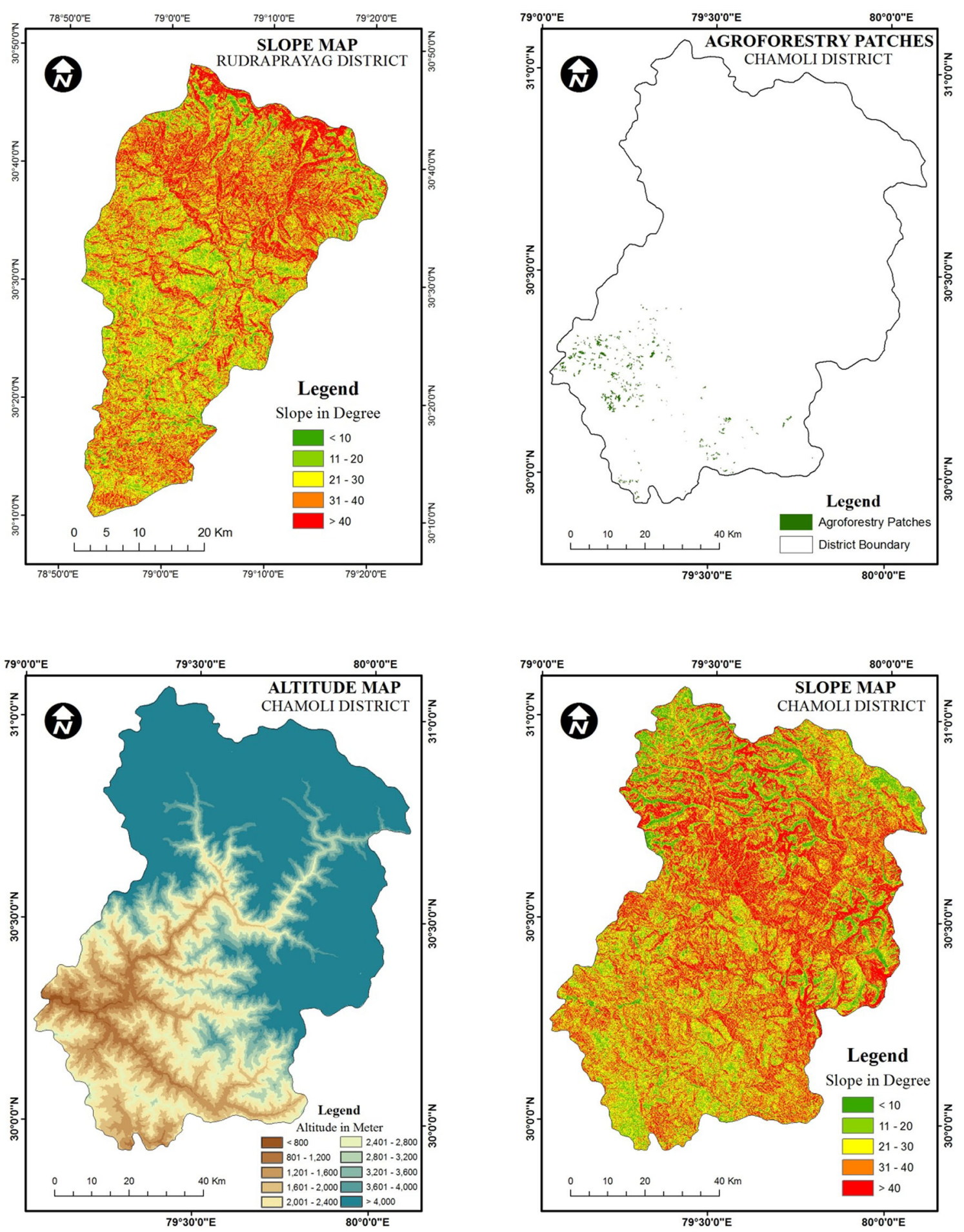

Fig. 5 continued

\section{Discussion}

Spatial patterns of ecosystems in the Himalayan landscape are determined by the interaction of ecological, policy and human factors. In western Himalaya, agroforestry is the

traditional land use of local communities. The traditional agroforestry systems in use around the world are very much lively and support not only the flexible ecosystems but also the associated biodiversity without investment of public costs (Toledo et al. 2003). In agroforestry system 
tree species also provide positive impact on agriculture crop production through nutrient transfer (Shepherd et al. 1996). Traditional agroforestry also has a good potential as mitigation strategy to changing climate because of its potential to sequester carbon in its multiple plant species and soil (Montagnini and Nair 2004; ICAR 2006).

Precise estimate of agroforestry area is not known in the Indian context. The country-level estimated area is not based on revenue record or actual measurements. India has declared National Agroforestry Policy 2014 (Dhyani 2014), which aims to estimate the area of agroforestry. In the current study, it was found that area under agroforestry

Table 2 Percent of area after overlaying elevation and slope classes of agroforestry practices in all four districts

\begin{tabular}{llrrrr}
\hline Elevation (m a.s.1.) & \multicolumn{5}{l}{ Slope $\left({ }^{\circ}\right)$} \\
\cline { 2 - 6 } & $\leq 10$ & $11-20$ & $21-30$ & $31-40$ & $\geq 41$ \\
\hline$\leq 800$ & 1.80 & 1.41 & 1.40 & 0.61 & 0.14 \\
$801-1200$ & 3.85 & 12.50 & 15.17 & 8.65 & 1.89 \\
$1201-1600$ & 3.07 & 12.79 & 16.31 & 8.85 & 1.80 \\
$1601-2000$ & 0.52 & 2.32 & 2.73 & 1.42 & 0.21 \\
$2001-2400$ & 0.26 & 0.81 & 0.87 & 0.39 & 0.07 \\
$\geq 2401$ & 0.01 & 0.04 & 0.05 & 0.03 & 0.00 \\
\hline
\end{tabular}

$(1.09 \%)$ in this part of western Himalaya is lower than the area under agroforestry $(8.2 \%)$ of the country (Dhyani et al. 2013). There is big gap between net shown area and agroforestry area in the four districts which means whole agriculture land has not been converted into agroforestry and further agroforestry in this part of Himalaya is fodder and fuel based. It needs to be converted into semi-commercial agroforestry based on market. These are dearth of wood based products not only in this part of Himalaya but at regional as well as national level too. Initiative needs to be taken by people as well as extension workers to introduce few more species especially of fruit and wood which have marketability and can fetch handsome amount sustainability to farmers; one such species is Populus ciliata (Pahari pipal) which is quick growing, deciduous, and can be harvest in $6-8$ years (Uniyal and Todaria 2006, 2003). It is indigenous to this place and has same utility as other species of Populus. Presently only 4-5 species are grown throughout the region as agroforestry trees.

No data are available in the country and also in the world that reveal the impact of altitude and slope on agroforestry land use system. Bagwari and Todaria (2011) calculated the highest energy $\left(10.55 \times 105 \mathrm{MJ} \mathrm{ha}^{-1}\right.$ year $^{-1}$ ) output from agroforestry in $1200-1600 \mathrm{~m}$ a.s.l. altitudinal zone in Rawanganga micro-watershed in

Table 3 Altitude-wise agriculture practices

\begin{tabular}{|c|c|c|c|c|c|c|}
\hline \multirow[t]{2}{*}{ Botanical name } & \multirow[t]{2}{*}{ Family } & \multirow[t]{2}{*}{ Showing time } & \multirow[t]{2}{*}{ Harvesting time } & \multicolumn{3}{|c|}{ Altitude (m) } \\
\hline & & & & ALT_1 & ALT_2 & ALT_3 \\
\hline Allium сера $\mathrm{L}$. & Amaryllidaceae & January-February & April-May & $\mathrm{Y}$ & $\mathrm{Y}$ & $\mathrm{Y}$ \\
\hline Brassica juncea $\mathrm{L}$. & Brassicaceae & October-November & April-May & $\mathrm{Y}$ & $\mathrm{Y}$ & $\mathrm{Y}$ \\
\hline Dolichos uniflorus & Fabaceae & June-July & October-November & $\mathrm{Y}$ & $\mathrm{Y}$ & $\mathrm{N}$ \\
\hline $\begin{array}{l}\text { Echinochloa crus-galli L. } \\
\text { (Beauv) }\end{array}$ & Poaceae & June-July & October-November & $\mathrm{Y}$ & $\mathrm{Y}$ & $\mathrm{Y}$ \\
\hline Eleusine coracana (Gaerth) & Poaceae & June-July & October-November & $\mathrm{Y}$ & $\mathrm{Y}$ & $\mathrm{N}$ \\
\hline Glycine max L.(Merr) & Fabaceae & June-July & October-November & $\mathrm{N}$ & $\mathrm{Y}$ & $\mathrm{Y}$ \\
\hline Lactuca sativa $\mathrm{L}$. & Asteraceae & June-July & October-November & $\mathrm{Y}$ & $\mathrm{Y}$ & $\mathrm{N}$ \\
\hline Lens culinaris Medikus. & Fabaceae & October-November & April-May & $\mathrm{Y}$ & $\mathrm{Y}$ & $\mathrm{N}$ \\
\hline Oryza sativa $\mathrm{L}$ & Poaceae & June-July & October-November & $\mathrm{Y}$ & $\mathrm{Y}$ & $\mathrm{Y}$ \\
\hline Paspalum scrobiculatum L. & Poaceae & June-July & October-November & $\mathrm{N}$ & $\mathrm{N}$ & $\mathrm{Y}$ \\
\hline Pisum sativum $\mathrm{L}$. & Fabaceae & October-November & February-March & $\mathrm{Y}$ & $\mathrm{N}$ & $\mathrm{N}$ \\
\hline Solanum tuberosum L. & Solanaceae & $\begin{array}{l}\text { January-February, } \\
\text { December-January }\end{array}$ & April-May, March-April & $\mathrm{Y}$ & $\mathrm{Y}$ & $\mathrm{Y}$ \\
\hline Triticum aestivum L. (Gehun) & Poaceae & October-November & April-May & $\mathrm{Y}$ & $\mathrm{Y}$ & $\mathrm{Y}$ \\
\hline Vigna mungo L. (Hepper) & Fabaceae & June-July & October-November & $\mathrm{Y}$ & $\mathrm{Y}$ & $\mathrm{N}$ \\
\hline Zea mays $\mathrm{L}$. & Poaceae & June-July & September-October & $\mathrm{Y}$ & $\mathrm{N}$ & $\mathrm{Y}$ \\
\hline Zingiber officinale Roscoe. & Zingiberaceae & $\begin{array}{l}\text { November- } \\
\text { December, } \\
\text { August-September }\end{array}$ & $\begin{array}{l}\text { September-October October- } \\
\text { November }\end{array}$ & $\mathrm{Y}$ & $\mathrm{Y}$ & $\mathrm{N}$ \\
\hline
\end{tabular}

$\mathrm{Y}=$ cultivated, $\mathrm{N}=$ not cultivated, ALT_1 = altitude up to $800 \mathrm{~m}$ a.s.1., ALT_2 = altitude 801-1200 $\mathrm{m}$ a.s.1., ALT_3 = altitude 1201-1600 m a.s.l. 


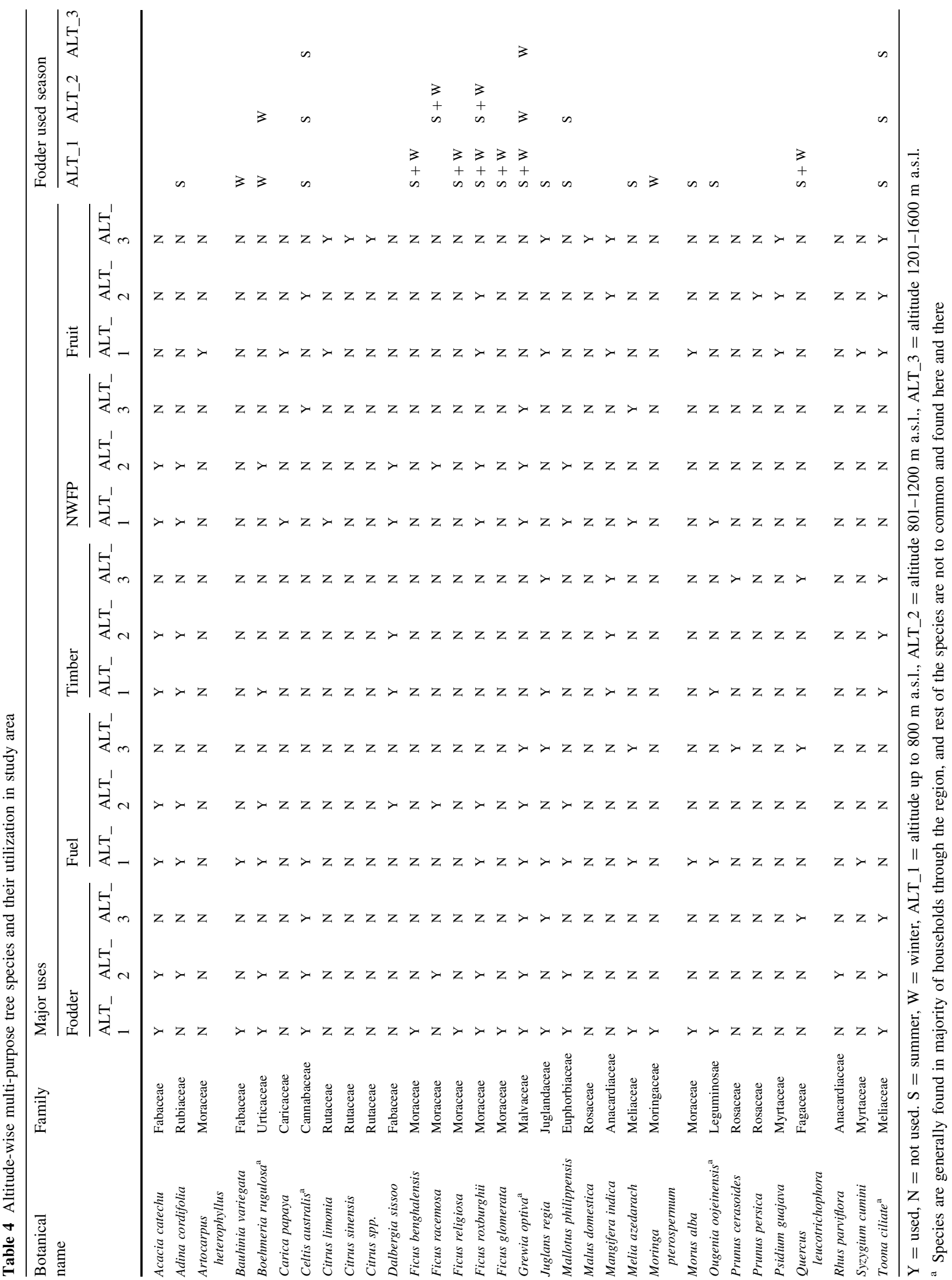


Garhwal Himalaya. Similarly, the present study also found the higher contribution of agroforestry in the same altitude. However, the number of tree and agriculture crop species adopted in the agroforestry is less in this altitudinal zone. Tsunehiro (2010) found that the slope has a positive impact on total factor productivity in Kenya. In case of present study, maximum agroforestry land was found between $21^{\circ}$ and $30^{\circ}$ slope and this could be because of more availability of land for terrace based agriculture. Secondly in valleys people do not prefer trees in and around agriculture field. Generally agriculture above $10^{\circ}$ slope is prone to erosion and low productivity. Therefore, emphasis should be on commercial agroforestry on slopes above $10^{\circ}$ slope which would not only fetch more income but shall also conserve soil.

As per farmer's perception, the income increases through the marketing of fruit from their agroforestry field. It is also perceived that leguminous tree species provide positive effects on agricultural crops. Wide variations in terms of net sown area and agroforestry area shows the potential area left out without agroforestry. In case of Pauri, $18.88 \%$ area out of total geographical is being used for agriculture activity, but only $1.05 \%$ out of net sown area is used as agroforestry, and migration to plains is very common in this districts. Bahuguna and Belwal (2013) studied the migration in rural area of Pauri district and found out that of the total migration, $28.75 \%$ people's main occupation was agriculture. There may also be scarcity of fodder for domestic animals coupled with low income from their agricultural field (Negi and Todaria 1993). Almost all of migrated people relied only on agricultural products, and agroforestry was never thought of a solution to solve their problem. Expanding/extending agroforestry practices could be one of the solutions in controlling migration of people from the mountains of western Himalaya. However, a policy decision on part of the government in this regard is needed because there are restrictions on harvesting/cutting and transport of wood products in states as well as at national level.

Given the fact that there is still lot of land potentially available for conversion into the agroforestry system, thus there are opportunities to increase land productivity of the agricultural lands in western Himalaya. This subsequently may stop some of the ongoing migration from the mountainous areas of this part of Himalaya.

Agroforestry is key path to prosperity for millions of farm families leading to extra income, employment generation, greater food and nutrient security, and meeting other basic human needs in a sustainable manner. As mitigation strategy to climate change as well as rehabilitation of degraded land, the conversion of pure cultivated agriculture crop land into agroforestry is a major opportunity as it helps carbon sequestration and makes land productive and reduces further soil degradation in terrace agriculture system.

Acknowledgments Authors gratefully acknowledge the financial assistance received from the South Asia Regional Office, International Centre for Research in Agroforestry (ICRAF), New Delhi, India. The help provided by the villagers of Tehri Garhwal, Pauri Garhwal, Rudraprayag, and Chamoli districts is also greatly acknowledged.

\section{References}

Bagwari HK, Todaria NP (2011) Resource use pattern and agroecosystem functioning in Rawanganga micro watershed in Garhwal Himalaya, India. J Agric Rural Dev Trop Subtrop 112(2):101-112

Bahuguna P, Belwal OK (2013) Regression model approach for outmigration on demographic aspects of rural areas of Pauri Garhwal. Int J Manag Soc Sci Res 2(8):175-182

Dhyani SK (2014) National Agroforestry policy 2014 and the need for area estimation under agroforestry. Curr Sci 107(1):9-10

Dhyani SK, Sharda VN (2005) Agroforestry systems as rural development options for the Indian Himalayas. J Tree Sci 24(1):1-19

Dhyani SK, Kareemulla KA, Handa AK (2009) Agroforestry potential and scope for development across agro-climatic zones in India. Indian J For 32(2):181-190

Gilmour DA, Nurse MC (1991) Farmer initiatives in increasing tree cover in central Nepal. Mt Res Dev 11:329-337

Handa SK, Uma AK (2013) Area under agroforestry in India: an assessment for present status and future perspective. Indian $\mathbf{J}$ Agrofor 15(1):1-11

ICAR (2006) Handbook of Agriculture, 5th edn. Indian Council of Agricultural Research, New Delhi

Kothari A (1994) Reviving diversity in India's agriculture. Seedling 14:1-4. http://www.grain.org/seedling/index.cfm?id=393. Accessed 23 July 2009

Kumar S (2010) Know your state Uttarakhand. Arihant Publication (i) Pvt. Ltd, Meerut, p 208

Maikhuri RK, Rawat LS, Phondani PC, Negi VS, Farooquee NA, Negi C (2009) Hill agriculture of Uttarakhand: policy, governance, research issues and development priorities for sustainability. India Econ Rev 6:116-123

Montagnini F, Nair PKR (2004) Carbon sequestration: an underexploited environmental benefit of agroforestry systems. Agrofor Syst 61:281-295

Negi AK, Todaria NP (1993) Studies on the impact of local folk on forests of Garhwal Himalaya. Biomass Bioenergy 4(6):447-454

NRCAF, Vision 2050 (2013) National Research Centre for Agroforestry, Jhansi, p 30

Ralhan PK, Negi GCS, Singh SP (1991) Structure and function of the agroforestry system in the Pithoragarh district of Central Himalaya: an ecological viewpoint. Agric Ecosyst Environ 35:283-296

Semwal RL, Maikhuri RK (1996) Structure and functioning of traditional hill agroecosystems of Garhwal Himalaya. Biol Agric Hortic 13:267-289

Sharma R, Sharma E, Purohit AN (1995) Dry matter production and nutrient cycling in agroforestry systems of mandarin grown in association with Albizia and mixed tree species. Agrofor Syst 29:165-179

Shepherd KD, Ohlsson E, Okalebo JR, Ndufa JK (1996) Potential impact of agroforestry on soil nutrient balances at the farm scale in the East African Highlands. Fertil Res 44(2):87-99 
Shiva V (1996) Towards a biodiversity based productivity framework. ILEIA Newsl 12:22-24

Shiva V, Vanaja RP (1993) Cultivating diversity: biodiversity conservation and seed politics. Research foundation for Science Technology and Natural Resource Policy. Natraj Publishers, Dehradun, $\mathrm{p} 130$

Singh V and Jardhari V (2001) Landrace renaissance in the mountains: Experiences of the Beej Bachao Andolan in the Garhwal Himalayan region, India. In: Proceedings international symposium on participatory plant breeding and participatory plant genetic resources enhancement, Cali, Columbia, IDRC, pp 87-96

Singh GS, Rao KS, Saxena KG (1997) Energy and economic efficiency of the mountain farming system: a case study in the north-western Himalaya. J Sustain Agric 9:25-49

Sundriyal RC, Rai SC, Sharma E, Rai YK (1994) Hill agroforestry systems in south Sikkim, India. Agrofor Syst 26:215-235

Thapa GB, Sinclair FL, Walker DH (1995) Incorporation of indigenous knowledge and perspectives in agroforestry development. Part 2: case study on the impact of explicit representation of farmers' knowledge. Agrofor Syst 30:249-261

Toky OP, Kumar P, Khosla PK (1989) Structure and function of traditional agroforestry systems in the western Himalaya. I. Biomass and productivity. Agrofor Syst 9:47-70

Toledo VM, Ortiz-Espejal B, Cortes L, De Jesus Ordonez M (2003) The multiple use of tropical forests by indigenous peoples in Mexico: a case of adaptive management. Conserv Ecol 7:9-12

Tsunehiro O (2010) Estimating agroforestry's effect on productivity in Kenya: an application of a treatment effects model. OSIPP discussion paper: DP-2010-E-001

Uniyal AK, Todaria NP (2003) Rooting characteristics of Populus ciliata Wall. Ex Royle as influenced by source, season and parental stock in Garhwal Himalaya, India. Ann For 11(2):233-244

Uniyal AK, Todaria NP (2006) Provenance-progeny trial for domestication of Populus ciliata clones. J Trop For Sci 18(4):269-273

Uttarakhand Forest Statistics (2012) Forest Department of Uttarakhand 